\title{
COVID-19 vaccination campaign: dialogues with nurses working in Primary Health Care
}

\author{
Campanha de vacinação contra COVID-19: diálogos com enfermeiros atuantes na \\ Atenção Primária à Saúde \\ Campaña de vacunación contra COVID-19: diálogos con enfermeros actuantes en la \\ Atención Primaria de Salud
}

How to cite this article:

Souza JB, Potrich T, Bitencourt JVOV, Madureira VSF, Heidemann ITSB, Menegolla GCS. COVID-19 vaccination campaign: dialogues with nurses working in Primary Health Care. Rev Esc Enferm USP. 2021;55:e20210193. DOI: http://dx.doi.org/10.1590/1980-220X-REEUSP-2021-0193

\section{D) Jeane Barros de Souza ${ }^{1}$ \\ Tassiana Potrich ${ }^{1}$ \\ Julia Valeria de Oliveira Vargas Bitencourt $^{1}$ \\ iD Valéria Silvana Faganello Madureira ${ }^{1}$ \\ D Ivonete Teresinha Schülter Buss \\ Heidemann ${ }^{2}$}

Gisielle Christine Schmidt Menegolla ${ }^{3}$

${ }^{1}$ Universidade Federal da Fronteira Sul, Chapecó, SC, Brazil.

${ }^{2}$ Universidade Federal de Santa Catarina,

Departamento e Programa de Pós-Graduação em Enfermagem, Florianópolis, SC, Brazil.

${ }^{3}$ Prefeitura Municipal de Chapecó, Chapecó, SC, Brazil.

\begin{abstract}
Objective: To reflect on the perception of nurses working in Primary Health Care about the development of the COVID-19 vaccination campaign. Method: This is a participatory action qualitative study, based on the methodological theoretical precepts by Paulo Freire, which consists of three interconnected phases: Thematic Research, Coding and Decoding, and Critical Unveiling. Three virtual Culture Circles were held between February and March 2021, with 11 nurses from Primary Health Care, residing in Santa Catarina, Brazil. Results: Nurses defined two themes for discussion in the Culture Circle: 1 . Matches in the COVID-19 vaccination campaign, representing the potentialities; 2. Mismatches in the COVID-19 vaccination campaign, in which the weaknesses were revealed. Conclusion: Nurses indicated potentialities such as teamwork, with hope, motivation, and joy in the vaccination campaign operationalization, through innovative and old actions. They also highlighted weaknesses such as lack of specific training and communication, difficulties with recording and application of the immunobiological, mentioning the anti-vaccine movement and the intense work, which requires adjustments to improve assistance to the population.
\end{abstract}

DESCRIPTORS

Coronavirus Infections; Pandemic; Nursing; Vaccines; Mass Vaccination. 


\section{INTRODUCTION}

The pandemic caused by Coronavirus Disease 2019 (COVID-19) affected the world, showing high mortality and transmissibility. Due to its severity and rapid progression, medications were used, but none of them were specific for the disease ${ }^{(1)}$. In this scenario, the vaccine emerged as a real possibility to stop the advance of COVID-19 in the world, aiming to reduce cases of worsening with a consequent decrease in deaths.

The race for the COVID-19 vaccine is still a challenge, but it is already being viable due to the investments and partnerships made by the governments of developed countries, pharmaceutical companies, and non-governmental institutions that seek safe and effective vaccines ${ }^{(2)}$. In Brazil, Fiocruz and Instituto Butantan were the most prominent in the research of COVID-19 vaccines, in partnership with international laboratories. Finally, in January 2021, given the urgency to save lives and avoid the collapse of the health system, part of the Brazilian population began to be vaccinated through the National Plan for the Operationalization of COVID-19 Vaccination ${ }^{(3)}$.

Vaccines are offered in Brazil by the Brazilian Public Health System $(S U S)$, through the National Immunization Program $(P N I)$, which is internationally recognized for its success in this area. However, ensuring access to doses requires extensive planning of production, storage, distribution, and vaccination campaigns. In the country, there are 36 thousand immunization rooms registered in the $S U S^{(4)}$. However, in the pandemic situation, this number shows a significant increase, given the urgency to guarantee immunization to the greatest number of people, in the shortest time possible, according to the availability of immunobiologicals.

When considering the reduced number of COVID-19 vaccine doses purchased by the Ministry of Health $(M S)$, the $P N I$ needed to establish priority groups to define the population to be immunized first, according to the greatest potential health risk ${ }^{(4)}$. According to data provided by the $M S$, around 13 million doses had already been applied in the Brazilian population until mid-March $2021^{(5)}$. It should be noted that the two immunobiologicals available so far require two doses to complete the vaccine schedule. Therefore, the number of doses applied still does not correspond to the number of people immunized.

It should be noted that, since the launch of the PNI, the organization of the entire process involving vaccination is the responsibility of the nurse and the nursing team ${ }^{(6)}$. In confronting COVID-19, in various health sectors, the nursing teams evidenced the strength of their work as protagonists in care provision. Thus, in the COVID-19 vaccination campaign, these professionals continued to play a leading role, appearing as indispensable for achieving the desirable vaccination coverage.

Faced with such complexity and responsibility imposed by the pandemic scenario, the question is: how is the development of the COVID-19 vaccination campaign taking place, in the nurses' perception? This is a new phenomenon, with few published studies on the subject, which warrants this investigation that aimed to reflect on the perception of nurses working in Primary Health Care (PHC) on the development of the COVID-19 vaccination campaign.

\section{METHOD}

\section{TyPe OF Study}

This is a participation action qualitative study ${ }^{(7)}$, based on the precepts of educator Paulo Freire. Therefore, the Research Itinerary was followed, built based on its theoretical and philosophical framework, since Freire does not make formal conceptual structures explicit as a research strategy, but as a production of a method of awareness, of learning. Thus, the Itinerary integrates three dialectical and interconnected stages: I) Thematic Research; II) Coding and Decoding; III) Critical Unveiling( ${ }^{(8)}$.

The Thematic Investigation is the first moment in which dialogue is encouraged, bringing out the generating themes, which are more broadly discussed and shared by the participants in the Culture Circle. Themes Coding is translated into contradictions and meanings of the situations experienced by the participants, and Decoding occurs when, through dialogue, one can recognize the reality, becoming aware of it through reflection on actions. In Critical Unveiling, the magical view is overcome, with critical reflection on reality in search of a transforming action, in a process of action-reflection $^{(8)}$.

To go through the stages of the Research Itinerary, three Culture Circles were developed. These circles are a space formed by a group of people to discuss common themes through dialogical praxis, in a horizontal and participatory manner, to promote collective knowledge and achieve transformation of reality ${ }^{(8-9)}$. It should be noted that in the first two Culture Circles, nurses discussed the meanings of the COVID-19 vaccine. In the third, they reflected on the development of the vaccination campaign, and in this article the reflections emerging from the last meeting will be addressed.

\section{Design and Local of Study}

The study had the participation of nurses who worked in PHC in different locations in Santa Catarina, Brazil. To organize the research members, first a nurse from the researchers' social network was invited by telephone. Through the snowball sampling method ${ }^{(10)}$, this nurse invited another participant to join the Culture Circle, and so on, with twelve professionals being invited and eleven agreeing to share the study, with one refusal.

As inclusion criteria, the following were considered: nurses working in PHC and who were working in the COVID-19 vaccination campaign. As exclusion criteria: not having access to the internet and electronic devices to participate and being on a leave during the study period.

In view of the pandemic scenario, the researchers chose to carry out the Culture Circles virtually ${ }^{(9)}$, using the digital platform Google Meet. The camera of electronic devices (computer or cell phone) was used to allow interaction among participants, even when they were geographically distant. 


\section{Data Collection}

Three virtual Culture Circles $(C C V)$ were held between February and March 2021, lasting approximately two hours each, having one of the authors as mediator, who is a nurse, Ph.D., with experience in this type of approach.

The researchers contacted all study participants by telephone, explaining the research objectives, when they defined the day and time for the first meeting. From then on, the second and third meetings were scheduled with the group, which decided together on the best day and time for them to happen.

To encourage dialogue and interactively go through the Freirean Research Itinerary, the mediator questioned the nurses about something symbolic that represented the moment they were experiencing and opted for the application of the COVID-19 vaccine. Thus, an analogy was made between the application of the vaccine and the phases of the Freirean Research Itinerary, through something concrete and current in the nurses' experience, as illustrated in Figure 1.

For the Thematic Investigation, the first stage of the Freirean Itinerary, the mediator pointed out the various investigations that nurses carried out for the development of the COVID-19 vaccination campaign. Thus, with a syringe in her hands, symbolically containing the COVID-19 vaccine, she urged nurses to investigate and reflect, making the following question: how is the development of the COVID-19 vaccination campaign?

To answer the question, nurses were asked to write a word or phrase on the shared computer screen. All participants presented their perspectives to the group. After extensive dialogue, the mediator reread all the words described and encouraged the nurses to organize them, according to the reflections that emerged. Thus, the group defined two generating themes for discussion in the third

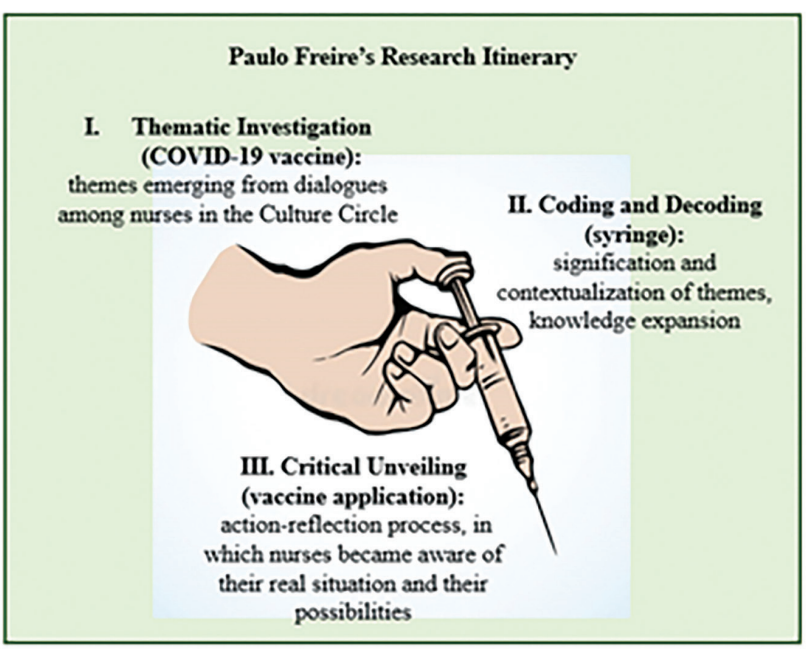

Figure 1 - Paulo Freire's research itinerary: analogy with the application of the COVID-19 vaccine.

Source: Image adapted from https://pt.dreamstime.com/seringa-\%C3\%A0disposi\%C3\%A7\%C3\%A3o-desenho-do-vetor-image 109200545
$C C V$ : 1. Matches during the COVID-19 vaccination campaign; 2. Mismatches during the COVID-19 vaccination campaign.

For the second stage of Freire's Itinerary, Coding and Decoding, the mediator again held the syringe in her hands, showing that it was necessary and significant in the application of the COVID-19 vaccine. From then onwards, she invited the participants to seek meanings and expand their knowledge about the generating themes, making two questions: what are the matches found during the COVID-19 vaccination campaign? What are the mismatches found during the COVID-19 vaccination campaign?

The nurses talked about the matches and mismatches during the vaccination campaign, while the mediator registered, through a sentence, the main shared meanings. These notes were read to all nurses, aiming at validating them. The mediator instigated the continuation of reflections on the proposed themes, in a process of action-reflection, encouraging them to understand together the possibilities of facing shared challenges and transforming their reality ${ }^{(8-9)}$.

In the Critical Unveiling, the last stage of the Freirean Itinerary, it was pointed out that society is anxiously awaiting the results of the COVID-19 vaccination. At that moment, the mediator encouraged the group to reflect on the possibilities of overcoming the challenges in the vaccination process and asked them: what was it like to have participated in this $\boldsymbol{C} \boldsymbol{C} \boldsymbol{V}$ ? The nurses spoke about their participation in the Culture Circle, which ended with everyone singing together the chorus of the song "O que é, que é?", by Gonzaguinha.

With the nurses' due authorization, the $C C V$ dialogues were recorded, transcribed, and organized in digital folders, according to the two generating themes chosen for discussion.

\section{Data Analysis}

The unveiling of the themes took place throughout the development of the $C C V$, as indicated in Paulo Freire's Research Itinerary, in a continuous analytical process. Thus, it is worth noting that data analysis in the Freirean Research Itinerary takes place permanently, with the participation of all those involved in the Culture $\mathrm{Circle}^{(8-9)}$.

\section{Ethical Aspects}

The research was compliant with the ethical principles of resolution 466/12 and 510/16, being approved by the Research Ethics Committee of the Universidade Federal da Fronteira Sul, with opinion number 4.068.387, on June 3, 2020. It should be noted that, in the first $C C V$, the mediator presented the research objectives and read the Free Informed Consent Form, inviting participants to sign and return it by email. To ensure anonymity, nurses were identified by the surname of nursing theorists.

\section{RESULTS}

Eleven nurses working in PHC, residing in different cities on the coast of Santa Catarina, Brazil, participated in the study, ten women and one man, with professional experience ranging from three to 20 years. During the $C C V$, 


\begin{tabular}{|l|l|}
\hline Matches found in the & $\begin{array}{l}\text { 2) Mismatches found in the } \\
\text { COVID-19 vaccination campaign }\end{array}$ \\
COVID-19 vaccination campaign \\
Nursing teamwork \\
Union of several institutions \\
Communication problems \\
Motivation \\
Happiness when going to work
\end{tabular}

Figure 2 - Representation of Coding and Decoding of the two generating themes. Source: Image adapted by the authors from https://br.pinterest.com/pin/624522673310236770/.

the nurses coded and decoded two generating themes, represented in Figure 2.

In discussions on the first generating theme, the participants reflected on the matches found during the COVID-19 vaccination campaign, which were considered by nurses as potentialities in this process. They highlighted the nursing teamwork as a positive factor, with the integration of various institutions, reflecting feelings of hope, motivation, and joy:

In this campaign, nursing has done a beautiful teamwork (Peplau).

Very cool to see the union of several institutions, clinics and universities that have been working with us on the campaign (Henderson).

Hope arose, a hope of new times (Leninger).

I leave home motivated to work on the campaign (Travelbee).

I am feeling immense joy in working on this campaign (...) (Nightingale).

The nurses said that several old actions were rescued and unveiled the insertion of new strategies, to maintain social distancing, especially of the elderly population, so that participation in the vaccination campaign has reflected in several lessons, with the opportunity to act in other places:

We rescued several old actions, such as active search, home vaccination (Horta).

In this campaign, we innovated and organized online scheduling and the drive-thru, which was a way to keep social distancing of the elderly (Patterson).

We have learned a lot: to be more resilient, to develop teamwork, as well as new knowledge, which is constantly coming in about vaccines (Roy).

I like to leave the unit and act in other scenarios during the campaign. (Orem).

Study participants revealed that there was greater enthusiasm in society because of the vaccination campaign and greater recognition of the relevance of nursing in the actions carried out, with them receiving several tributes:

Society is more excited, we realize this during our work (King).
I've received several tributes, such as flowers and cakes. Society seems to be recognizing the importance of Nursing, being aware of how hard we are working in various sectors in this pandemic, to promote the population's health (Levine).

In the reflections of the second generating theme, in which they revealed the mismatches, understood as difficulties during the vaccination campaign, the nurses highlighted the lack of effective communication among all those involved as one of the challenges, which has repercussions on obstacles in recording data, in the application of immunobiologicals, and in confusion between the doses and vaccines available in the SUS. In this regard, they discussed about the need for more specific guidance for acting in vaccination:

We have serious problems of communication within all levels of care and this creates numerous problems (Peplau).

It's complicated dealing with the records. When registering in the system, data are missing and sometimes these data do not match (Henderson).

There are difficulties even in the vaccine application, because there are professionals who are working on the campaign, but have no experience in handling and applying immunobiologicals (Leninger).

We now have two vaccines available, Coronavac and AstraZeneca. Sometimes there is confusion between vaccines, between doses and schedules. It would be easier if we had a single dose and a single vaccine, as in the flu campaign (Orem).

We should have more specific guidance on various details, to avoid problems during the campaign and achieve more satisfactory results (Nightingale).

Another difficulty exposed was the intense work, with labor shortage, and the nurses believe that the campaign will be long. Moreover, they highlighted the feeling of intense heat, given the need to wear personal protective equipment $(\mathrm{PPE})$ in non-refrigerated places, which even make it difficult to maintain the temperature of immunobiologicals:

This campaign is taking a lot of work, because it will make workers spend a lot of time (Levine). 
(...) besides the vaccine, we have to attend the general public and the entire situation of people diagnosed and suspected of COVID-19. So, there is labor shortage (King).

It's hard to wear all the PPEs with that heat in the drive-thru (...) it even makes it difficult to maintain the vaccines' ideal temperature (Roy).

The need to carry out an active search and the antivaccination movement were also cited as obstacles for the nursing team:

There are people who are not returning for the second dose. Many older people have not yet registered to receive the vaccine. We have to make an active search, which also demands more time and personnel (Patterson).

I think the anti-vaccination movement is present in society and I have seen people who have the right to take the vaccine and don't want to, out of fear (Roy).

The nurses highlighted the relevance of participating in the $C C V$ :

It was great to have participated in all the meetings and I felt relieved to know that in all places there are problems similar to ours here (Orem).

I was very bappy to participate. I learned from you here, thank you very much (Patterson).

I appreciate that you listened to me and I was heard. I needed this, to share my yearnings (...) I leave this transformed (Nightingale).

\section{DISCUSSION}

COVID-19 vaccination is surrounded by symbols that show, exuberantly or subtly, the position of this strategy in the control of the pandemic. The concept that the vaccine provides unrestricted immunization may be the result of a magical thought that denotes exhaustion and despair of people regarding the definitive containment of the disease. However, on the other side, there is a proportion of the Brazilian population that assumes denialism regarding the immunizing effects of vaccines ${ }^{(11)}$. The infodemic surrounding COVID-19 and vaccine hesitation reflect the tension between the scientifically validated risk and the subjectively perceived risk, also influenced by the crisis of trust in science and in the actions of the federal government ${ }^{(12)}$.

In this scenario with intense emotional and workload, nurses dialogued in the $C C V$, sharing their perceptions about the vaccination campaign. When reflecting on the first generating theme, in which they discussed about the matches or potentialities of the vaccination campaign, elements were unveiled that highlighted the importance of nursing professionals, added to the relevance of teamwork and partnership between teaching and service institutions.

Fortuitously, in this period of pandemic, there is debate about the spotlight focused on nursing, and this appreciation takes place in parallel with the "Nursing Now" campaign, developed mainly in 2020. In this respect, hopes were raised that this distinction will last after the pandemic and the valorization, now explored, has repercussions in the nursing work process, with regard to people management, worker's safety, remuneration, among many other factors present in the professional context.

It is urgent that, beyond the necessary valorization, nursing finds greater political and social support to reconcile the exercise of permanent training, improving itself for clinical practice, aiming to provide ever-increasing resoluteness in health care ${ }^{(13)}$. In addition, to meet the demand of the National Vaccination Plan, partnerships were reinforced, imprinted by concepts and ideas of teaching and service integration, with cooperation and the structuring of task forces in teamwork during the pandemic period, never being so envisioned ${ }^{(14)}$.

In this COVID-19 vaccination campaign, daily nursing practices were renewed, which provided new learning on a topic around which knowledge has been structured in real time.

It was also necessary to use strategies already established in primary health care services, whose resolution is factual, such as active search and home vaccination, aiming to achieve immunization coverage and provide vaccination to all priority groups, as established by the $M S$, reorganizing their work processes to achieve positive results ${ }^{(15)}$.

The training apparatus is part of the set of measures to be provided, given the peculiarity of the health context for which knowledge is still totally new ${ }^{(16)}$. Training shall take place before organization itself and the action in a health service that, in this case, also involves the techniques implicated in vaccination and in campaign management ${ }^{(17)}$.

It should be noted that the Pan American Health Organization (PAHO) launched a campaign, in partnership with the $M S$, aimed at the mental health of professionals who daily experience the collapse of the system in the context of the pandemic. In these settings, vaccination had perceptible psychological effects on the well-being of professionals and emerged renewing hope, encouraging professionals to persist in facing this serious global health crisis $^{(18)}$.

In the reflections on the second generating theme, in which the mismatches experienced in the COVID-19 vaccination campaign were discussed, the participants critically commented on challenges to be overcome, pointing out aspects that denote problems in the work process and that involve different dimensions: management, education, assistance, and politics.

Therefore, when specifying the management of vaccines itself, interference was observed regarding the availability of doses, an assertive definition of the type to be used, considering the existence of two distinct sources distributed in Brazil: Coronavac, produced by Instituto Butantan, and AstraZeneca, from Fiocruz. Both vaccines have two doses, with different intervals between them ${ }^{(3)}$, which can lead to confusion in the records and misleading guidance to the community.

Continuing education aimed at this vaccination was perceived as insufficient, lacking technical guidance. It should be noted that the $M S$ defined the National Plan for 
Operationalization of COVID-19 vaccination, establishing guidelines as a source of support for Federal Units and municipalities in the planning and development of the vaccination campaign ${ }^{(3)}$. However, the success of this action will only be possible according to the involvement of the three spheres of management in coordinated efforts in the SUS, to achieve adequate care and population adhesion ${ }^{(3)}$.

Although this plan has the objective of equipping management bodies in the operationalization of vaccination, it is worth reflecting that the process occurred suddenly in Brazil, with little time for municipalities to prepare professionals, who learned during the course of the campaign.

In people management, the number of professionals to work in the campaigns was questioned, as well as the expected activity time for each professional and the ambience. Professionals directly and indirectly involved in coping with COVID-19 are daily exposed to the risk of becoming ill, which is associated with working conditions, labor shortage, physical fatigue, and psychological stress due to insufficiency and/or negligence in relation to the protection measures and health care.

For this reason, it is urgent to avoid the reduction of work capacity and quality of care for the population ${ }^{(19)}$. In this regard, it is up to nurses to promote actions that articulate, together with unions, associations, and professional councils, the organization of debates on the loss of labor rights and current forms of work, seeking to improve policies in defense of workers and for better working conditions and salaries ${ }^{(20)}$.

Although nurses are one of the main actors in this scenario and their performance has been recognized by society, their valorization was not. One of the examples is the struggle for rights, such as the minimum wage and the thirty hours a week of work, which have been in Congress for years, without being analyzed and voted on. In addition, the need to organize the vaccination campaign in a short time exposed professional exhaustion and long working hours, as well as the confrontation of situations such as the loss of family members and professional colleagues to COVID-19, which endorses the concern with these professionals' physical and mental health ${ }^{(21)}$.

In assistance, there were difficulties in communication, which were reflected, above all, in the organization of the active search. Communication is a crucial tool in the entire care process, so that professionals pass on relevant data accurately and clearly, aiming at the continuity of care to individuals and communities. When effective, it is directly linked to the safety of the person being cared for, as it allows the recording of information consistent with the entire care process, which includes active search, besides providing a harmonious work environment, free from damage ${ }^{(22)}$.

In the political sphere, the nurse was also required to confront the "anti-vaccine" movement. This ideological movement is not new, as it began with the Vaccine Revolt, in 1904, and has remained alive until the present day, being a real threat to the population by disseminating information without a scientific basis, through virtual activism. The scarcity of information about the immunization process and people's lack of discernment about the health-disease process are another challenge for nurses on the front line of immunization practice ${ }^{(23)}$.

It is worth highlighting health education as a fundamental strategy for the development of immunization in society, emphasizing its importance for disease prevention, which promotes vaccination coverage expansion, and raises the population's awareness regarding self-care ${ }^{(15)}$.

It should be noted that the choice of applying the vaccine as a metaphor to instigate discussions in the $C C V$ was important to bring the study participants closer to reality. However, nursing needs to be recognized in its social role, for its ability to support the achievement of access and universal health coverage, as these professionals acquire scientificallybased skills and knowledge in their training ${ }^{(24)}$, going far beyond the technicist model, aiming at meeting the individuals' and communities' health needs.

In the political scenario, it is noteworthy that, historically, nursing is disjointed with regard to the development of the profession and the fight for better working conditions. Therefore, at this moment, it is necessary to raise these professionals' mobilization and politicization, to achieve greater social recognition and transform reality ${ }^{(25)}$.

In the light of the foregoing, the applicability of the Virtual Culture Circle is unveiled as an innovative space to hold meetings that promote dialogue, reflection, and the emancipation of individuals through mutual learning and the sharing of knowledge and experiences, which can be used in various spheres of the health sector, especially in times of social restrictions.

It is worth noting that the results of this investigation contribute to the evidence-based practice of nurses in the development of the COVID-19 vaccination campaign, encouraging reflections on the matches and mismatches in the care provided to the population. As limitations of the study, there is the challenge of reconciling a time with all nurses to carry out the $C C V$, due to the accumulation of activities they develop in their work process, especially in coping with COVID-19.

\section{CONCLUSION}

In the $C C V$, nurses shared their experiences in the work process, during the COVID-19 vaccination campaign, in which some potentialities were highlighted, such as the relevance of teamwork, support from other institutions, greater enthusiasm in society, which echoed feelings of hope, motivation, and joy. The applicability of innovative actions such as drive-thru and online scheduling for vaccination was also evident, with the recovery of old activities such as active search and immunization at home, with matches thus emerging in the vaccination operationalization.

The PHC nurses also reflected on the weaknesses in the immunization process, in which challenges emerged, such as the lack of effective communication, difficulties with records and application of the immunobiological, showing a shortage of professionals and specific training to work in the campaign. They also highlighted the anti-vaccination 
movement and the intense work faced with the reality of a long campaign. These factors provide subsidies for the search for improvement in the operationalization of the vaccination campaign, as it is believed that it will be a long process, which requires adjustments in favor of the qualification of care for the population and the work of the professionals involved. Furthermore, it is time for nursing to wake up to political involvement in favor of greater social recognition, in the fight for better conditions in its work process.

\section{RESUMO}

Objetivo: Refletir sobre a percepção de enfermeiros atuantes na Atenção Primária à Saúde sobre o desenvolvimento da campanha de vacinação contra a COVID-19. Método: Estudo qualitativo, tipo ação participante, fundamentado nos preceitos teóricos metodológicos de Paulo Freire, que consiste em três fases interligadas: Investigação Temática, Codificação e Descodificação, Desvelamento Crítico. Realizaram-se três Círculos de Cultura virtual, entre fevereiro e março de 2021, com 11 enfermeiros da Atenção Primária à Saúde, residentes em Santa Catarina, Brasil. Resultados: Os enfermeiros definiram dois temas para discussão no Círculo de Cultura:1. Encontros na campanha de vacinação COVID-19, representando as potencialidades; 2. Desencontros na campanha de vacinação COVID-19, em que desvelaram as fragilidades. Conclusão: Os enfermeiros apontaram potencialidades como a atuação em equipe, com esperança, motivação e alegria na operacionalização da campanha de vacinação, por meio de ações inovadoras e antigas. Também evidenciaram fragilidades como falta de formação específica e comunicação, dificuldades com os registros e a aplicação do imunobiológico, salientando o movimento antivacina e o intenso trabalho, o que carece de ajustes em prol da qualificação da assistência à população.

\section{DESCRITORES}

Infecções por Coronavírus; Pandemia; Enfermagem; Vacinas; Vacinação em Massa.

\section{RESUMEN}

Objetivo: Reflexionar sobre la percepción de enfermeros actuantes en la Atención Primaria de Salud sobre el desarrollo de la campaña de vacunación contra COVID-19. Método: Estudio cualitativo, tipo acción participante, fundamentado en los preceptos teóricos metodológicos de Paulo Freire, que consiste en tres etapas interconectadas: Investigación Temática, Codificación y Descodificación; Revelación Crítica. Se realizaron tres Encuentros de Cultura virtual, entre febrero y marzo de 2021, con 11 enfermeros de la Atención Primaria de Salud, residentes en Santa Catarina, Brasil. Resultados: Los enfermeros definieron dos temas para debate en el Encuentro de Cultura: 1. Logros en la campaña de vacunación contra COVID-19, en que revelaron las potencialidades; 2. Dificultades en la campaña de vacunación contra COVID-19, en que revelaron las vulnerabilidades. Conclusión: Los enfermeros destacaron potencialidades como el trabajo en equipo, con esperanza, motivación y alegría en la operacionalización de la campaña de vacunación, por medio de acciones innovadoras y antiguas. También destacaron vulnerabilidades como ausencia de formación específica y comunicación, dificultades con los registros y aplicación del inmunobiológico, evidenciando el movimiento antivacuna y el intenso trabajo, el que demanda más ajustes para lograr calificar la asistencia a la población.

\section{DESCRIPTORES}

Infecciones por Coronavirus; Pandemia; Enfermería; Vacunas; Vacunación Masiva.

\section{REFERENCES}

1. Ita K. Coronavirus Disease (COVID-19): current status and prospects for drug and vaccine development. Arch Med Res. 2021;52:15-24. DOI: https://doi.org/10.1016/j.arcmed.2020.09.010.

2. Domingues CMAS. Desafios para a realização da campanha de vacinação contra a COVID-19 no Brasil. Cad Saude Publica. 2021;37(1):e00344620. DOI: https://doi.org/10.1590/0102-311x00344620.

3. Brasil. Ministério da Saúde. Plano Nacional de Operacionalização da vacinação contra COVID-19. [Internet]. Brasília; 2020 [cited 2021 mar. 09]. Available from: https://www.gov.br/saude/pt-br/media/pdf/2021/janeiro/25/planovacinacaocovid_v2_25jan21.pdf.

4. Stevanim LF. Uma vacina para a humanidade: da expectativa à realidade, os esforços para se chegar a uma vacina contra a covid-19 acessível à população. RADIS Comunicação e Saúde. [Internet]. 2020 [cited 2021 mar. 09];15(216):12-21. Available from: https://www. arca.fiocruz.br/bitstream/icict/43683/2/VacinaParaHumanidade.pdf.

5. Brasil [Internet]. Ministério da Saúde. Conselho Nacional de Saúde. Vacinômetro: CNS reúne informações sobre vacinação contra Covid-19 em cada estado no Brasil. [cited 2021 mar. 02]. Available from: http://conselho.saude.gov.br/ultimas-noticias-cns/1653vacinometro-cns-reune-informacoes-sobre-vacinacao-contra-covid-19-em-cada-estado-no-brasil.

6. Martins JRT, Viegas SMF, Oliveira VC, Rennó HMS. Vaccination in everyday life: experiences indicate Permanent Education. Esc. Anna. Nery. 2019;23(4):1-8. DOI: https://doi.org/10.1590/2177-9465-ean-2018-0365.

7. Felcher CDO, Ferreira ALA, Folmer V. Da pesquisa-ação à pesquisa participante: discussões a partir de uma investigação desenvolvida no Facebook. Experiências em Ensino de Ciências [Internet]. 2017 [cited 2021 mar. 02];12(7):1-18. Available from: https://if.ufmt.br/ eenci/artigos/Artigo_ID419/v12_n7_a2017.pdf.

8. Heidemann ITSB, Dalmolin IS, Rumor PCFR, Cypriano CC, Costa MFBNA, Durand MK. Reflexões sobre o itinerário de pesquisa de Paulo Freire: contribuições para a saúde. Texto contexto - enferm. 2017;26(4):e0680017. DOI: https://doi.org/10.1590/010407072017000680017.

9. Naderifar M, Goli H, Ghaljaie F. Snowball sampling: A purposeful method of sampling in qualitative research. Strides Dev Med Educ. 2017;14(3):1-6. DOI: https://doi.org/10.5812/sdme.6767010.

10. Souza JB, Potrich T, Brum CN, Heidemann ITSB, Zuge SS, Lago AL. Repercussions of the COVID-19 pandemic from the childrens' perspective. Aquichan. 2020;20(4):e2042. DOI: https://doi.org/10.5294/aqui.2020.20.4.2.

11. Morel APM. Negacionismo da Covid-19 e educação popular em saúde: para além da necropolítica. Trab. educ. saúde. 2021;19:e00315147. DOI: https://doi.org/10.1590/1981-7746-sol00315. 
12. Couto MT, Barbieri CLA, Souza AMCC. Considerations on covid-19 impact on the individual-society relationship: from vaccine hesitancy to the clamor for a vaccine. Saude soc. 2021;30(1):e200450. DOI: https://doi.org/10.1590/S0104-12902021200450.

13. Spagnol CA, Pereira MS, Cunha CT, Pereira KD, Araújo KLS, Figueiredo LG, et al. Holofotes acesos durante a pandemia da COVID-19: paradoxos do processo de trabalho da Enfermagem. Rev Min Enferm. 2020;24:e-1342. DOI: http://www.dx.doi. org/10.5935/1415.2762.20200079.

14. Franzoi MAH, Cauduro FLF. Atuação de estudantes de enfermagem na pandemia de Covid-19. Cogitare enferm. 2020;25:e73491. DOI: http://dx.doi.org/10.5380/ce.v25i0.73491.

15. Souza PA, Gandra B, Chaves ACC. Experiências sobre imunização e o papel da atenção primária à saúde. APS em Revista. 2020;2(3): 267-271. DOI: https://doi.org/aps10.14295/aps.v2i3.57.

16. Bitencourt JVOV, Meschial WC, Frizon G, Biffi P, Souza JB, Maestri E. Protagonismo do enfermeiro na estruturação e gestão de uma unidade específica para COVID-19. Texto contexto - enferm. 2020;29:e20200213. DOI: https://doi.org/10.1590/1980-265xtce-2020-0213.

17. Fregene TE, Nadarajah P, Buckley JF, Bigham S, Nangalia V. Use of in situ simulation to evaluate the operational readiness of a highconsequence infectious disease intensive care unit. Anaesthesia. 2020;75(6):733-8. DOI: https://dx.doi.org/10.1111/anae.15048.

18. Dantas ESO. Saúde mental dos profissionais de saúde no Brasil no contexto da pandemia por Covid-19. Interface (Botucatu). 2021;25(Suppl.1):e200203. DOI: https://doi.org/10.1590/interface.200203.

19. Teixeira CFS, Soares CM, Souza EA, Lisboa ES, Pinto ICM, Andrade LR, et al. A saúde dos profissionais de saúde no enfrentamento da pandemia de Covid-19. Ciênc. saúde coletiva. 2020;25(9):3465-3474. DOI: https://doi.org/10.1590/1413-81232020259.19562020.

20. Settani SS, Silva GBS, Julião IHT, Silva MCF, Silva JCB, Oliveira DAL, et al. Comunicação de enfermagem e as repercussões na segurança do paciente. Rev enferm UFPE online. 2019;13:e239573. DOI: https://doi.org/10.5205/1981-8963.2019.239573.

21. Vedovato TG, Andrade CB, Santos DL, Bitencourt SM, Almeida LP, Sampaio FS. Trabalhadores(as) da saúde e a COVID-19: condições de trabalho à deriva? Rev bras saúde ocup. 2021;46:1-15. DOI: https://doi.org/10.1590/2317-6369000028520.

22. Cornwall Jun BW. Just 50\% of Americans plan to get a COVID-19 vaccine. Here's how to win over the rest. [cited 2020 June 30]. Available from: https://www.sciencemag.org/news/2020/06/just-50-americans-plan-get-covid-19-vaccine-here-s-how-win-over-rest.

23. Andrade FF, Leandro CL, Vargas IC, Cruz MEG, Oliveira PK, Gomes MS. Movimento antivacina: uma ameaça real. Revista Científica Multidisciplinar Núcleo do Conhecimento. 2021;6(2):72-79. DOI: https://doi.org/10.32749/nucleodoconhecimento.com.br/saude/ ameaca-real.

24. Neto MVM, Rewa T, Leonello VM, Oliveira MAC. Advanced practice nursing: a possibility for Primary Health Care?. Rev Bras Enferm. 2018;71(Suppl 1):716-21. DOI: https://doi.org/10.1590/0034-7167-2017-0672.

25. Lessa ABSL, Araújo CNV. A enfermagem brasileira: reflexão sobre sua atuação política. Rev Min Enferm. 2013; 17(2):474-480. DOI: http://www.dx.doi.org/10.5935/1415-2762.20130036. 